\title{
6. Campaigns for land and citizenship rights: the dynamics of transnational agrarian movements ${ }^{1}$
}

\author{
SATURNINO M. BORRAS AND \\ JENNIFER C. FRANCO
}

\section{Introduction}

During the past two decades nation-states in the South have been greatly transformed by a triple squeeze, namely: 'from above' through globalization, with some regulatory powers being ceded to international regulatory institutions; 'from below', through the partial decentralization of political, fiscal and administrative powers to local counterparts; and 'from the sides', through the privatization of some functions (Fox 2001). Central states remain important, albeit transformed, players in local, national and international politics and economics (Keohane and Nye 2000).

The changing international, national and local institutions that structure the rules under which poor people assimilate into or resist the corporate-controlled global politics and economics have presented both threats and opportunities to the world's rural population. This has encouraged and provoked national rural social movements to further localize (in response to state decentralization), and at the same time to internationalize (in response to globalization) their movements, advocacy and lobbying work, and collective actions, while holding on to their national characters. One result of this adjustment is the emergence of more horizontal, 'polycentric' rural social movements that at the same time struggle to construct coherent structures for greater vertical integration. The seemingly contradictory political directions of globalization and decentralization are thus also transforming the political-organizational processes of rural social movements.

Meanwhile, the nature of land rights and the location, power and authority of the institutions governing them have altered during the past decades. Since the Mexican Revolution ushered in the modern era of redistributive land reform in 1910, subsequent land reforms have followed many trajectories. But two broad paths were dominant: capitalistoriented, with small family farming as an important component, and 
socialist-oriented, with collective and state farms as a key feature. The Cold War era led to a sharp divide between these two models, eventually drawing bilateral and multilateral development agencies to the land issue. The United States Agency for International Development (USAID), partly through the Alliance for Progress, was perhaps the most prominent of all agencies promoting a pre-emptive type of land reform across the world, aimed at containing the spread of communism. By the late 1970s USAID had started to carry out the earliest relatively coherent experiments in what would later become known as 'market-led agrarian reform'. This period also witnessed an aggressive role by the World Bank on the same pre-emptive land reforms, but also in private land titling programmes.

Amid talk about the demise of land reform, and with peasant-based national liberation movements still active in many parts of the world, the UN's Food and Agriculture Organization (FAO) convened the World Conference on Agrarian Reform and Rural Development (WCARRD) in 1979, hoping to widen the agenda. Conventional redistributive land reform, to be achieved through central government policy and emphasizing the significant role of small family farms, was among the key elements of the WCARRD Declaration, but this turned out to mark the beginning of the end of redistributive land reform. Aside from a handful of scattered land reform initiatives, the 1980 os witnessed the fading out of land reform from global and national development policies.

The failure of structural adjustment programmes forced mainstream economists to think again about the productive assets of the rural poor, and land was resurrected in development discourses in the 199os. Advocacy during this decade and onwards was marked by calls for privatization of collective and state farms in ex-socialist countries, promotion of decentralized non-state management of (forest) land resources, and the invention and subsequent promotion of market-led agrarian reform, based on the principle of land market dynamics and a 'willing sellerwilling buyer' formula. Bilateral and multilateral development agencies also started to pay serious attention to land policies.

From 2003 to 2008, all bilateral and multilateral development agencies formulated their own distinct policies on land, gravitating around market-oriented frameworks inspired by new institutional economics. Meanwhile, from the mid-1990s onwards, scattered but dramatic land struggles have also occurred. These struggles were subsequently internalized by transnational agrarian movements, such as Vía Campesina, which later, in the 1990s, would emerge to become important global political actors. These 'initiatives from above' by international agencies 
and 'actions from below' by agrarian movements were largely responsible for the FAO convening a second global conference, the International Conference on Agrarian Reform and Rural Development (ICARRD), held in 2006 in Brazil. During the latter part of this period, while agrarian movements were actively mobilizing on the local and national scenes, they also frequently started to systematically extend their actions into the global terrain. Multilateral and bilateral agencies have taken a wide and coherent interest in land policies, and have intervened in them, pushing for non-state, market-driven and decentralized approaches to land reform. These contradictory currents have brought various actors together at different levels of the policy arena, resulting in both clashes and alliances.

It remains to be seen whether or not ICARRD will, like WCARRD, turn out to signal the end of another period of land policy reformism. But the post-2006 terrain seems to be less favourable to redistributive land policies. The promotion of market-oriented land policies and the recent food and fuel crisis may prove to be an explosive combination, possibly resulting in massive dispossession of the rural poor worldwide. National governments and transnational companies are currently hunting for land in the South that can be 'captured' to produce food and biofuel for export. Whether or not such efforts are successful will depend, in part, on existing land policies. Settings that have witnessed significant promotion of market-oriented land policies are likely to be where such far-reaching changes in land use and property control will happen. But political contestations around the global land grab have occurred, and will occur, at the local, national and transnational levels.

Understanding the dynamics of transnational agrarian movements (TAMs) and their struggles for land and citizenship rights requires an interrelated analysis of several actors, factors and dimensions in transnational politics. The rest of this chapter is organized around these issues, with a particular focus on one TAM, Vía Campesina, and analysis of its global campaign against neoliberal land reform.

\section{The emergence of transnational agrarian movements (TAMs)}

Transnational networks and social movements are not new. Several transnational agrarian movements, organizations, networks or coalitions, of varying size, sectoral focus, ideological provenance and political orientation, have existed in the past. Among the oldest remaining groups is the International Federation of Agricultural Producers (IFAP), founded in 1946 by farmers' associations mainly from developed countries. IFAP has become the mainstream agricultural organization, 